\title{
PRODUCTION OF PRINTING AND WRITING PAPER GRADE PULP FROM ELEPHANT GRASS
}

Keywords: Grasses

Soda pulping Bleaching

Histórico:

Recebido 09/06/2016

Aceitol3/09/2016

Palavras chave: Gramíneas

Polpação soda

Branqueamento

Correspondência: andrade-marcela@hotmail.com

DOI:
ABSTRACT: The main goal of this study was to characterize chemically and morphologically elephant grass (Pennisetum purpureum), and evaluate the potential of its fibers for production of printing and writing paper grade pulp. The elephant grass was chemically and morphologically characterized and cooked by the soda process to two different degrees of delignification (kappa 17.5 and 10.6). The resulting pulps were fully bleached by the O-D*-(EP)-D sequence and characterized for their beatability, drainability and physical-mechanical properties. The lignin content $(20.2 \%)$ was low, indicating that this grass should be easier to pulp. The morphological analyses of the elephant grass indicated a short fiber material, similar to hardwoods. The soda pulp from elephant grass cooked to kappa number 17.5 presented higher screened yield than 10.6 kappa pulp, with alkali demands of $15.0 \%$ and $20.0 \%$, respectively. The total active chlorine required by the 17.5 and 10.6 kappa pulps, were 42.1 and $35.1 \mathrm{~kg} /$ odt pulp, respectively, to achieve an ISO brightness of approximately $90.0 \%$. The bleached soda pulps cooked to 17.5 and 10.6 kappa number showed similar refinability and resistance to drainage, but the tensile and burst index were highest for the 17.5 kappa pulp at beating energy consumptions in the range of 0-6 Wh. It was concluded that both 10.6 and 17.5 kappa pulps from elephant grass are suitable for the production of printing and writing paper grade pulps, but the highest kappa 17.5 pulp is more economically attractive given its highest pulping yield, despite the significantly increased of chemical demand for bleaching A produção de papel para impressão e escrita Grau de celulose a partir de capim-elefante.

\section{A PRODUÇÃO DE PAPEL PARA IMPRESSÃO E ESCRITA A PARTIR DE DA POLPA DE CAPIM-ELEFANTE}

RESUMO: O principal objetivo desse estudo foi caracterizar química e morfologicamente o capim elefante (Pennisetum purpureum), e avaliar o potencial das suas fibras para a produção de polpa para papéis de impressão e escrita. $\bigcirc$ capim elefante foi caracterizado química e morfologicamente e cozinhado pelo processo soda com dois diferentes graus de deslignificação (número kappa 17,5 e 10,6). As polpas resultantes foram completamente branqueadas pela sequência O-D*-(EP)-D e caracterizadas quanto as suas refinabilidades, drenabilidades e propriedades físico-mecânicas. O conteúdo de ligina $(20,2 \%)$ foi baixo, indicando ser uma gramínea fácil polpação. A análise morfológica do capim elefante indicou ser um material de fibra curta, semelhante a madeiras de folhosas. A polpa de capim elefante cozida pelo processo soda até número kappa 17,5 apresentou maior rendimento depurado que a polpa de kappa 10,6 com uma demanda de álcali de 15,0\% e 20,0\%, respectivamente. O cloro ativo total requerido para as polpas de kappa 17,5 e 10,6 foi de 42, I e 35, I kg/tas, respectivamente, para atingirem uma alvura de aproximadamente $90,0 \% \mathrm{ISO}$. As polpas cozidas pelo processo soda até números kappa 17,5 e 10,6 e branqueadas apresentaram valores similares de refinabilidade e resistência à drenagem, mas o índice de tração e arrebentamento foram maiores para a polpa com número kappa 17,5 até atingirem uma energia de consumo de na faixa de 0-6 Wh. Foi concluído que ambas as polpas de capim elefante com kappas 10,6 e 17,5 são apropriadas para a produção de papéis de imprimir e escrever, sendo a polpa de maior número kappa economicamente mais atraente dado o seu rendimento de polpação superior, sem significativo aumento da demanda de reagentes químicos de branqueamento.

I Federal University of Viçosa - Viçosa, Minas Gerais, Brasil 


\section{INTRODUCTION}

Biomass from grasses is the largest renewable source for the production of bioproducts and biofuels; it is available in high amounts at relatively low cost. Elephant grass (Pennisetum purpureum) is originated from Africa and now introduced into most tropical and subtropical countries. It has a large genetic variability and is considered a species of fast growth and high production of plant biomass.

The renewed interest in non-wood fiber sources stems from the fact that they offer several advantages in the pulp and paper industry. Non-wood fibers can be used in most paper grades, including board, fiberboard (VERVERIS et al.,2004) and composite materials (SAIN and PANTHAPULAKKAL, 2006). According to Mazzarella (2007), the comparative advantages of elephant grass in relation to other biomass sources are: increased productivity (45 ton per ha per year), smaller cultivated areas for a particular production, lower production cycle (two harvests per year), better cash flow, mechanization, renewable energy and greater carbon assimilation. However, compared to wood, non-wood fibers sources present challenges with their seasonal (and not year-round) availability; handling, given their high volume, low density; and the large volumes of silica that have to be removed during processing (PANDEY, 2000).

Elephant grass is therefore considered to be an excellent feedstock to provide abundant and sustainable resources of lignocellulosic biomass for the production of energy, industrial chemicals, and/or pulp and paper (SOMERVILLE et al., 20I0); MADAKADZE et al. (20I0)). Elephant grass has beneficial characteristics for pulp production, such as high fibers production and its chemical composition (PRINSEN et al., 20I2); DEL RIO et al., 20I2; XIE et al., 20II). According to Madakadze et al. (2010), elephant grass contents of cellulose, hemicelluloses, and lignin are 40,30, and $18.0 \%$, respectively. These values are suitable for pulp production, especially the low lignin content, suggesting high pulpability of this material in cooking processes.

The aforementioned studies indicate that elephant grass has potential for paper production, but a more thorough investigation is required, particularly comparing its potential with that of the well-known eucalyptus wood. The main goal of this study was characterizing chemically and morphologically elephant grass, and evaluation of the potential of its fibers for production of printing and writing paper grade pulp.

\section{MATERIAL AND METHODS}

\section{Working plan}

Figure I depicts the working plan. The elephant grass was characterized chemically and morphologically, and converted into brown pulp of two different delignification degrees (kappa 17.5 and 10.6) by the soda pulping. The resulting pulps were fully bleached by the O-D*-(EP)-D sequence and characterized for their beatability, drainability and physical-mechanical properties.

\section{Elephant grass (EG)}

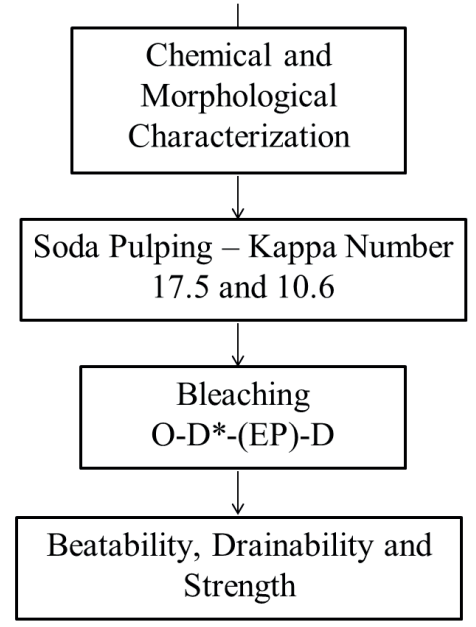

FIGURE I Working plan for EG fractionation

\section{Material}

About $100 \mathrm{~kg}$ of elephant grass (Pennisetum purpureum)) was collected at an age of 150 days old, from the experimental station of the University of Viçosa (Brazil). The sample was dried to about $85 \%$ dryness in an acclimated room $\left(23.0 \pm 1.0^{\circ} \mathrm{C}\right.$ and $50.0 \pm 2.0 \%$ moisture) and stored in polyethylene bags for further use. The air-dried sample was ground in a Wiley mill, sieved, and the fraction that passed through a 40 mesh screen and was retained in the 60 mesh screen was collected, air-dried and stored in wide mouth sealed flasks.

\section{Chemical characterization of elephant grass biomass}

The following procedures were used for chemical analysis: moisture content (TAPPI T 264 om88), total extractives content (TAPPI T $264 \mathrm{~cm}-97$ ), acid soluble lignin (GOLDSCHIMID, 197I), Klason lignin (GOMIDE and DEMUNER, I986), lignin syringyl/guaiacyl ratio (LIN and DENCE, I992), preparation of biomass 
for sugar analysis (TAPPI T $249 \mathrm{~cm}-85$ ), sugar analysis (WALLIS et al., 1996)), acetyl groups (SOLAR et al., 1987), uronic acids (SCOTT, 1979), silica (TAPPI T245 $\mathrm{cm}-98$ ) and ash (TAPPI 2 I I om 93).

\section{Morphological characterization of elephant grass biomass}

Elephant grass biomass was investigated for fiber dimensions. For the implementation of the morphological analysis, the sample was fragmented and Ig o.d. of each sample was macerated using 5 parts of acetic acid and I part of nitric acid during a time of 4 to 6 hours at chapel. Subsequently, the sample was washed in running water diluted with distilled water to favor the dispersion of the fibers. The analysis was performed in the sample after hydration and soft agitation for complete fiber individualization.

Microscopic blades were prepared and images were captured in a video microscope equipped with image analysis software (model SZ - STS, Olympus, Japan). Small amount of colorant (Astra blue) was added for better visualization of the fibers and about 100 whole fibers were measured. The following fiber biometric traits were measured: length, width, lumen diameter and cell wall thickness. Fiber length was measured with $70 \mathrm{X}$ magnification whereas the other traits were measured with 1000X magnification. The variation coefficient was taken at every 25 measurements. The data obtained by measurements were transferred to Office Excel 2007, which determined the averages, standard deviations, and variation coefficients.

From the fiber biometry measurements mathematical inferences were done to determine other fiber properties, namely: (I) Felting Index $(\mathrm{FI})=$ relation between fiber length (FL) and fiber width (FW), (FL.FW-1-1) 1000 , where, 1000 is a conversion factor of $\mu \mathrm{m}$ to $\mathrm{mm}$. (2) Flexibility Coefficient $(\mathrm{FC})=$ relation between lumen diameter (LD) and fiber width (FW), (LD.FW-1)*I00, where, 100 is a conversion factor for percentage. (3) Wall Fraction (WF), relation between wall thickness (WT) and fiber width (FW), (2*WT.FW-1 $)^{* 1} 100$, where, 100 is a conversion factor for percentage. (4) Ratio length/ thickness $\left(\mathrm{L} \cdot \mathrm{T}^{-1}\right)=$ relation between fiber length $(\mathrm{FL})$ and wall thickness (WT): (FL.WT-1)*1000. Where, 1000 is a conversion factor of $\mu \mathrm{m}$ to $\mathrm{mm}$. (5) Runkel Index $(\mathrm{RI})=$ relation between wall thickness (WT) and lumen diameter (LD), (2*WT.LD-1).

\section{Soda pulping}

The soda pulping was carried out in a $\mathrm{M} \cdot \mathrm{K}^{-1}$ digester (Systems Inc., Massachusetts - USA) with a capacity of 7 liters, equipped with forced circulation and heat exchanger devices, aiming at producing pulps with two different delignification degrees. It was conducted using the following parameters: ratio of liquor/biomass $8 \mathrm{~L} \cdot(\mathrm{l} \mathrm{kg})^{-1}$, maximum temperature $180^{\circ} \mathrm{C}$, time to maximum temperature of $60 \mathrm{~min}$, time at maximum temperature of $20 \mathrm{~min}$, and $15.0 \%$ and $20.0 \%$ alkali charges, to reach kappa number 17.5 and 10.6, respectively.

The following procedures were used for soda pulping analysis: Brightness (TAPPI T452 om-08), kappa number (TAPPI T236 om-06) and viscosity (TAPPI T230 om-08).

\section{Elemental Chlorine Free (ECF)Bleaching}

The two pulps resulting from the soda pulping at kappa 17.5 and 10.6 were fully bleached by the O-D*(EP)-D, sequence, where: $O=$ simple stage oxygen delignification; $D^{*}=$ hot chlorine dioxide stage; $(E P)=$ alkaline extraction with hydrogen peroxide; $D_{1}=$ chlorine dioxide bleaching stage. Table I describes the conditions used in each bleaching stage. After each bleaching stage, the residual liquor was extracted for pertinent analysis and the pulp samples were washed with an equivalent of $9 \mathrm{~m}^{3}$ of distilled warm water per ton of dry pulp. All experiments were run in duplicate.

\section{Physical-mechanical tests}

The pulps were beaten in a PFI mill at different energy inputs, made into hand sheets and tested for physical-mechanical properties according to TAPPI

TABLE I Conditions in each bleaching stage of elephant grass pulps from soda pulping

\begin{tabular}{cccccccccc}
\hline \multirow{2}{*}{ Parameters } & \multicolumn{3}{c}{ Kappa Number 17.5} & \multicolumn{6}{c}{ Kappa Number 10.6} \\
\cline { 2 - 9 } & $\mathrm{O}$ & $\mathrm{D}^{*}$ & $(\mathrm{EP})$ & $\mathrm{D}$ & $\mathrm{O}$ & $\mathrm{D} *$ & $(\mathrm{EP})$ & $\mathrm{D}$ \\
\hline Consistency $(\%)$ & 10 & 10 & 10 & 10 & 10 & 10 & 10 & 10 \\
Temperature $\left({ }^{\circ} \mathrm{C}\right)$ & 105 & 95 & 80 & 80 & 105 & 95 & 80 & 80 \\
Time $(\mathrm{min})$ & 70 & 120 & 90 & 120 & 70 & 120 & 90 & 120 \\
Pressure $(\mathrm{kPa})$ & 600 & - & - & - & 600 & - & - & - \\
$\mathrm{O} 2\left(\mathrm{~kg} \cdot \mathrm{odt}^{-1}\right)$ & 20.0 & - & - & - & 20.0 & - & - & - \\
$\mathrm{ClO} 2$, as Cl$^{2}$ & - & 10.8 & - & 25.0 & - & 8.8 & - & 20.0 \\
$\left(\mathrm{~kg} \cdot \mathrm{odt}^{-1}\right)$ & - & & & & & & 3.0 & \\
$\mathrm{H} 2 \mathrm{O} 2\left(\mathrm{~kg} \cdot \mathrm{odt}^{-1}\right)$ & - & - & 3.0 & & & & \\
$\mathrm{NaOH}\left(\mathrm{kg} \cdot \mathrm{odt}^{-1}\right)$ & 20.0 & - & 8.0 & 3.0 & 15.0 & - & 8.0 & 2.0 \\
$\mathrm{H} 2 \mathrm{SO} 4\left(\mathrm{~kg} \cdot \mathrm{odt}^{-1}\right)$ & - & 5.0 & - & - & - & 5.0 & - & - \\
$\mathrm{MgSO} 4\left({\mathrm{~kg} \cdot \mathrm{odt}^{-1}}^{-1}\right)$ & 1.5 & - & - & - & 1.5 & - & - & - \\
\hline
\end{tabular}

After bleaching the pulps were characterized for their beatability, drainability and physical-mechanical properties. 
standards (Table 2). The tests related to the tensile stresses were carried out by an Instron instrument, and the tear, burst and air resistance tests were carried out in Eldendorf, Müllen and Gurley porosimeter, respectively. Opacity and Scattering of the sheets were measured in Datacolor spectrophotometer, Elrepho 2000X Model.

TABLE 2 TAPPI standard methods used for PFI beating, hand sheet making and physical and mechanical properties

\begin{tabular}{cc}
\hline Parameters & TAPPI Standard Methods \\
\hline Grammage & TAPPI T4 I0 om-08 \\
Thickness & TAPPI T55 I om-06 \\
Tear Index & TAPPI T4 I4 om-04 \\
Burst Index & TAPPI T403 om-02 \\
Tensile Index & TAPPI T494 om-06 \\
Modulus of elasticity - MOE & TAPPI T494 om-96 \\
Tensile energy absorption - TEA & TAPPI T494 om-96 \\
Apparent Specific Volume - bulk & TAPPI T220 sp-0I \\
Apparent Specific density & TAPPI T220 sp-96 \\
PFI Beating & TAPPI T248 sp-08 \\
Forming Handsheets for physical tests & TAPPI T205 sp-95 \\
Air resistance & TAPPI T460 om-02 \\
Drainage resistance - Schopper Riegler & TAPPI T423 cm-07 \\
\hline
\end{tabular}

\section{Statistical analysis}

The pulp physical-mechanical properties obtained at different beating levels were statistically analyzed using the Curve Expert software. The adjusted equations were compared by $\mathrm{F}$ test, using the identity test models and adopting a significance level of up to $5 \%$ probability, according to the methodology described by Regazzi (1993) for linear models and Regazzi and Silva (2004) for nonlinear models.

\section{RESULTS AND DISCUSSION}

\section{Chemical characterization of elephant grass}

The contents of cell wall structural constituents (cellulose, hemicelluloses and lignin) in the elephant grass biomass are show in Table 3. Xylans (14.0\%) are the main hemicelluloses of elephant grass, with the contents of galactans, mannans and arabinans of this material being rather low.

The contents of glucans (39.9\%) and uronic acids (1.3\%) in elephant grass were similar to content of others non woody materials, such as sugar cane bagasse (ANDRADE and COLODETTE, 20I4)), but lower than eucalyptus woods (BATALHA et al., 2012; GOMES et al. , 2013). The low content of uronic acids can be negative, since the uronic acids act protecting the xylans during the alkaline pulping (MAGATON et al., 2008). The acetyl group content in the elephant grass $(2.1 \%)$ was similar to content of the others woody and non woody materials (ANDRADE and COLODETTE, 20I4; BATALHA et al. ,2012; BARBOSA et al., 2005).
TABLE 3 Chemical composition of elephant grass in percentage of biomass dry weight

\begin{tabular}{cc}
\hline Analyses , \% & Elephant grass \\
\hline Klason lignin & 18.1 \\
Acid soluble lignin & 2.1 \\
\hline Total lignin & 20.2 \\
\hline Lignin S/G & 1.1 \\
Glucans & 39.9 \\
Xylans & 14.0 \\
Galactans & 0.5 \\
Mannans & 0.0 \\
Arabinans & 1.1 \\
Uronic acids & 1.3 \\
Acetyl & 2.1 \\
\hline Total Sugars* & 58.9 \\
Ash & 6.0 \\
Silica & 1.5 \\
Extractives & 14.8 \\
Grand Total, \%** & 100 \\
\hline
\end{tabular}

*include glucans, xylans, galactans, mannans, arabinans, uronic acids and acetyl groups. **include total lignin, total sugars, ash and extractives.

The elephant grass biomass presented much larger amounts of non-structural constituents (extractives and minerals) in relation to woody biomass, such as eucalyptus (GOMES et al., 20I3; BARBOSA et al., 2005). The amount of ethanol/toluene extractives and minerals in the elephant grass were $14.8 \%$ and $6.0 \%$, respectively. These values are high when compared with eucalyptus woods. The silica was responsible for $25.0 \%$ of the elephant grass mineral contents.

The lignin c content of elephant grass (20.2\%) was low, indicating that this grass should be easier to pulp than wood with a lignin content of $26-30 \%$ (GOMES et al. 20I3)). The lignin content of elephant grass was similar to values reported in the literature. Values in the range of 18\%-21\% were reported by Gomes et al. (20I3); Del Rio et al. (20I2) and Madakadze et al. (20I0). Increased contents of ash, silica and extractives contents on elephant grass have been reported by the same authors. The high extractive and mineral contents are quite challengeable for pulp production. Besides causing a variety of operational problems (scaling, corrosion, pitch deposition, chemical degradation during bleaching, recovery boiler plugging, etc), minerals and extractives may cause severe difficulties during the bleaching if not properly removed during the process.

\section{Morphological characterization of the fibers}

The determination of pulp fibers biometry is quite relevant in the production of printing and writing paper grade pulp since they affect paper beatability, drainability and properties rather significantly. Table 4 shows the average biometry of the elephant grass fibers.

The average fiber length, fiber width, lumen diameter and wall thickness of the elephant grass was I.I mm, I4.7 $\mu \mathrm{m}, 7.9 \mu \mathrm{m}$ and $3.4 \mu \mathrm{m}$, respectively. 
TABLE 4 Elephant grass fiber dimensions

\begin{tabular}{ccc}
\hline Dimension & Statistic & Elephant Grass Biomass \\
\hline Fiber length, & Average & I.I \\
$\mathrm{mm}$ & Standard Deviation & 0.2 \\
& C.V., \% & 16.2 \\
Fiber width, & Average & 14.7 \\
$\mu \mathrm{m}$ & Standard Deviation & 3.5 \\
& C.V., \% & 23.8 \\
Lumen diameter, & Average & 7.9 \\
$\mu \mathrm{m}$ & Standard Deviation & 3.0 \\
Wall thickness, & C.V., \% & 37.8 \\
$\mu \mathrm{m}$ & Average & 3.4 \\
& Standard Deviation & 0.8 \\
\hline
\end{tabular}

*include glucans, xylans, galactans, mannans, arabinans, uronic acids and acetyl groups. **include total lignin, total sugars, ash and extractives.

In general, the fiber morphology of elephant grass is somewhat similar to those of many hardwoods, thus being qualified as short fibered materials. Other significant information can be obtained from biometry data through correlations among the various fiber dimensions. Table 5 shows the relations calculated based on the average value of each morphological parameter evaluated. These relations help understanding the influence of fiber morphology on paper formation and properties (FOELKEL and BARRICHELO, 1975). Fibers with a high Runkel index and wall fraction, and low flexibility coefficient are more rigid and present high tear resistance, which is a property dependent on the intrinsic strength of the fiber, but low tensile and burst indexes, which are properties that depend on fiber bonding (FOELKEL and BARRICHELO, 1975).

The elephant grass fibers showed a Runkel index (0.86) and wall fraction (46.3\%) values lower than those reported for eucalyptus woods, which were I.I-2.67 and 52-73\%, respectively (FOELKEL and BARRICHELO, 1975). The elephant grass flexibility coefficient value $(53.7 \%)$ was higher than that reported for eucalyptus woods (28-47\%). Pulps of high flexibility coefficient produce more inter-fiber bonding during beating, increasing tensile and burst

TABLE 5 Relations of morphological properties

\begin{tabular}{ccc}
\hline Relationship & Elephant Grass Biomass & Eucalyptus Hybrids* \\
\hline $\begin{array}{l}\text { Felting index } \\
\text { Flexibility } \\
\text { coefficient, \% }\end{array}$ & 74.8 & $48.0-59.0$ \\
$\begin{array}{l}\text { Wall fraction, \% } \\
\text { Ratio length/ } \\
\text { thickness }\end{array}$ & 53.7 & $28.0-47.0$ \\
Runkel index & 46.3 & $52.0-73.0$ \\
\hline * Foelkel, et al., I975 & 323.5 & $145.0-196.0$ \\
\hline
\end{tabular}

strengths. The felting index in elephant grass (74.8) was similar to that of other grasses, such as bagasse ( 70.0) reported by Carvalho (20I2), and higher than that of eucalyptus wood fibers (48-59) (FOELKEL and BARRICHELO, 1975). The length/thickness ratio of the depithed bagasse soda pulp was higher (323.5) than that of eucalyptus wood fibers (145-196) (FOELKEL and BARRICHELO, 1975) and similar to values of others grasses (CARVALHO, 20I2).

\section{Soda Pulping}

Table 6 shows the results of soda pulping of elephant grass to kappa numbers 17.5 and 10.6. The soda pulp of kappa 17.5 presented $46.1 \%$ screened yield (pulp viscosity of $1279 \mathrm{dm}^{3} \cdot \mathrm{kg}^{-1}$ ) against $44.6 \%$ yield (pulp viscosity of $1146 \mathrm{dm}^{3} \cdot \mathrm{kg}^{-1}$ ) for the 10.6 kappa pulp, with alkali demands of $15.0 \%$ and $20.0 \%$, respectively. It is conceivable that the highest pulp yield in elephant grass is attributable to its low lignin content and high alkali solubility. The reject contents were low in both cases $(<2 \%)$; this indicated that the soda pulping provided adequate defibering. Pulps originated from kappa numbers 10.6 achieved brightness values higher than pulps from kappa numbers 17.5, which is explained by the highest amount of lignin in the kappa 17.5 pulp. The largest fraction of pulp chromophores originates from lignin (GIERER, 1970) and only a small fraction from the decomposition of carbohydrates (FORSKAHL, et al. , 1976). The lowest pulp viscosity of the low kappa pulp is explained by the highest alkali charge used during the soda cooking. The soda acts degrading carbohydrates and breaking the chains of cellulose and hemicelluloses, thus affecting the viscosity.

Compared to eucalyptus, the elephant grass is easier to cook aiming at a kappa number of about 17-I8. Values of $25 \% \mathrm{NaOH}, 49.8 \%, 0.1 \%, 33.4 \%$ ISO, and $862 \mathrm{~cm}^{3} \cdot \mathrm{g}^{-1}$, have been reported for alkali charge, screened yield, rejects, brightness and viscosity, respectively, in the soda pulping of eucalyptus (ALMEIDA and GOMIDE, 20I2).

TABLE 6 Results of Soda Pulping*

\begin{tabular}{|c|c|c|c|c|c|c|c|}
\hline \multirow[b]{2}{*}{ Sample } & \multirow[b]{2}{*}{$\begin{array}{l}\text { Kappa } \\
\text { Number }\end{array}$} & \multirow[b]{2}{*}{$\begin{array}{r}\text { Alkali } \\
\quad(\%)\end{array}$} & \multicolumn{3}{|c|}{ Screened Total } & \multirow[b]{2}{*}{$\begin{array}{c}\text { Brightness } \\
\text { (\%ISO) }\end{array}$} & \multirow[b]{2}{*}{$\begin{array}{l}\text { Viscosity } \\
\left(\mathrm{dm} 3 \cdot \mathrm{kg}^{-1}\right)\end{array}$} \\
\hline & & & $\begin{array}{l}\text { Rejects } \\
(\%)\end{array}$ & $\begin{array}{c}\text { Yield } \\
(\%) \\
\end{array}$ & $\begin{array}{r}\text { Yield } \\
(\%) \\
\end{array}$ & & \\
\hline $\begin{array}{c}\text { Elephant } \\
\text { grass }\end{array}$ & 17.5 & 15.0 & 1.5 & 46.1 & 47.6 & 38.9 & 1279 \\
\hline $\begin{array}{c}\text { Elephant } \\
\text { grass }\end{array}$ & 10.6 & 20.0 & 0.3 & 44.6 & 44.9 & 45.3 & 1146 \\
\hline
\end{tabular}

**Soda pulping conditions: liquor/biomass: $8 \mathrm{~L} \cdot(\mathrm{lkg})^{-1}$, maximum temperature: $180^{\circ} \mathrm{C}$, time to maximum temperature: $60 \mathrm{~min}$, time at maximum temperature: $20 \mathrm{~min}$. 


\section{ECF Bleaching}

The elephant grass pulps were bleached by the O-D*-(EP)-D sequence to a target brightness of $90 \%$ ISO. The oxygen delignification (O) efficiencies, compared at fixed conditions and similar final reaction $\mathrm{pH}$ (10.6-10.8) was higher for the 17.5 kappa pulp (69.4\%) versus 10.6 kappa pulp (58.5\%); the post-O brightness values of the pulps were 48.5 and $54.6 \%$ ISO, respectively. The oxygen delignification efficiency is calculated based on kappa number before and after the oxygen stage. The behavior of brightness, kappa number and viscosity across the O-D*-(EP)-D sequence are shown in Figure 2.
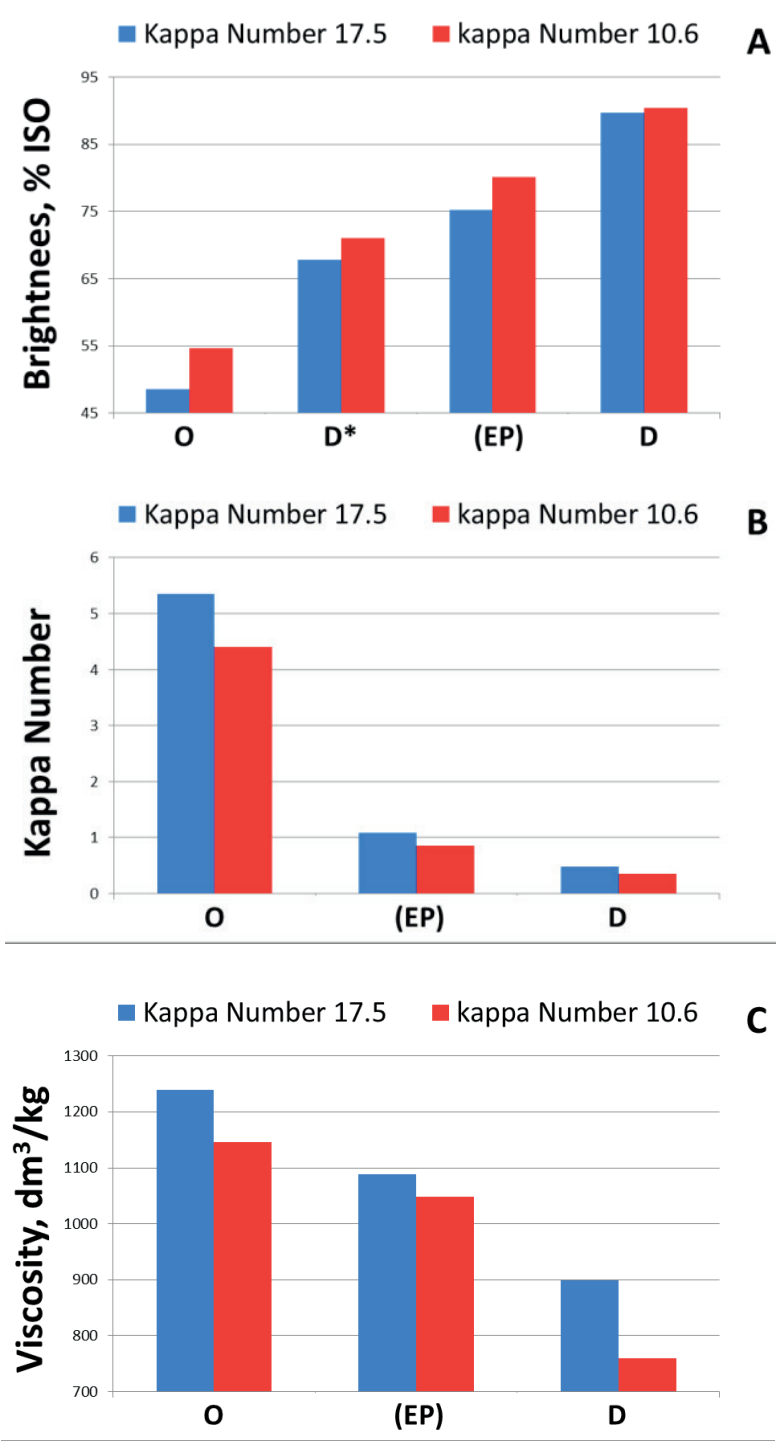

FIGURE 2 Position tree planting in the Cartesian plane trees in 1875 (Left,) and position of the sample with 200 trees (Right).
The brightness values across the sequence of bleaching were higher for pulps with kappa number 10.6 than pulps with kappa number 17.5. Except for the last stage of the bleaching sequence, where the difference in brightness values were similar for the two pulps ( $90.0 \%$ ISO), due to the high charge of chlorine dioxide used in the pulp from kappa number 17.5 for achieving the desired brightness value. The higher reduction in kappa number in $D^{*}$ treatment is explained by the high HexA removal in the $D^{*}$ stage, under high temperature and a long reaction time conditions (LACHENAL and CHIRAT, 2000), Furthermore, the main goal of reinforcing an extraction stage with $\mathrm{H}_{2} \mathrm{O}_{2}(E P)$ is to increase the amount of lignin removed (ANDERSON , 1992), resulting in substantial reduction in kappa number after this stage, values of I.I and 0.9 were found for the pulps of kappa number 17.5 and 10.6, respectively. The final kappa number values were similar for both pulps studied. The viscosity values decreased over the bleaching stages. The more severe cooking conditions used to obtain pulps with low kappa number, caused a decrease in carbohydrates contents with a negative influence on viscosity, this profile is observed in all stages of bleaching. The significant viscosity losses after the (EP) stage for both pulps were more likely to be caused by the high temperature used in $\mathrm{D}^{*}$ coupled with the low $\mathrm{pH}$ (acid hydrolysis of the glycolsidic linkages), and by the hydrogen peroxide used in the (EP) stage. The decomposition of hydrogen peroxide in the alkaline conditions generates free radicals which attack the cellulose fibers, thus reducing the viscosity of the pulp. According to Ventorim et al. (2009), pulps exposed to hot acid hydrolysis stage (e.g., D*) may experience some carbohydrate degradation, which is dependent upon reaction conditions. The bleached pulp final viscosities were 899 and $760 \mathrm{dm}^{3} \cdot \mathrm{kg}^{-1}$ for the 17.5 kappa and 10.6 kappa pulps, respectively.

The overall bleaching chemical consumptions by the kappa 17.5 and 10.6 pulps, measured as total active chlorine, were 42.1 and $35.1 \mathrm{~kg}$.(odt) $)^{-1}$ pulp, respectively, to achieve an ISO brightness of about $90.0 \%$. The post color numbers values were in the range of 0.37-0.5 I for both bleached pulps, indicating high brightness stability. The summary results of the bleaching by O-D*-(EP)-D sequence is showed in Table 7.

\section{Physico-mechanical tests}

The bleached pulps were beaten using different revolutions in the $\mathrm{PFI}$ mill $(0,500,1000,1500$ and 0 , 1000 , 1500, 2000 revolutions for pulps originated from soda pulping with final kappa number 17.5 and 
TABLE 7 Parameters estimates of the omnidirectional and cross semivariograms $\mathrm{Vol}=$ volume, $\operatorname{Exp}=$ Exponential.

Bleaching Parameter Kappa Number 17.5 Kappa Number 10.6

\begin{tabular}{|c|c|c|}
\hline $\begin{array}{l}\text { Total Active Chlorine }{ }^{*} \text {, } \\
\text { kg. odt }{ }^{-1}\end{array}$ & $42.1^{a}$ & $35.1^{\mathrm{b}}$ \\
\hline $\begin{array}{c}\text { Brightness, } \\
\% \text { ISO }\end{array}$ & $89.9^{a}$ & $90.4^{a}$ \\
\hline $\begin{array}{l}\text { Post Color } \\
\text { Number }\end{array}$ & $0.51^{a}$ & $0.37^{a}$ \\
\hline $\begin{array}{l}\text { Viscosity } \\
\mathrm{dm}^{3} \cdot \mathrm{kg}^{-1}\end{array}$ & $899^{a}$ & $760^{\mathrm{b}}$ \\
\hline
\end{tabular}

* Total Active Chlorine (kg·odt $\left.{ }^{-1}\right)=\mathrm{ClO} 2\left(\mathrm{~kg} \cdot \mathrm{odt}^{-1}\right) * 2.63+\mathrm{H} 2 \mathrm{O} 2\left(\mathrm{~kg} \cdot \mathrm{odt}^{-1}\right) * 2.09$. Note: The averages marked with the same letters in each line, are not significantly differentce by Tukey's test at a $5 \%$ significance level.

10.6, respectively) and subjected to physical and mechanical tests in order to evaluate their potential for the production of printing and writing paper grades. All the proprieties were expressed in relation to the energy consumed during beating given its contribution to paper production cost. For the mass production the consumption of energy during refining can represent up to $30 \%$ of the cost. Each graph shows the experimental data and the curves that describe the fitted models.

\section{Drainage Resistance and Beatability}

Pulp drainability can be loosely defined as the capacity of the pulp to drain the water from the mat. As this parameter increases, so does the tensile index. Pulp beatability can be loosely defined as the amount of pulp beating energy required to achieve a certain drainage degree. Therefore, the relationship between 'SR (Schopper-Riegler) and energy consumption, for example, gives a direct indication of pulp beatability. The highest amount of beating energy required to achieve a given ${ }^{\circ} S R$, the lowest is the pulp's beatability. Figure 3 shows the relations between ${ }^{\circ} \mathrm{SR}$ and tensile index (A) and ${ }^{\circ} \mathrm{SR}$ and energy consumption (B) for the bleached pulps with initial brownstock kappa numbers of 17.5 and 10.6. As anticipated, the resistance to drainage increased with increasing tensile index and the ${ }^{\circ} S R$ increased with increasing energy consumption. The drainage resistance and beatability were not influenced by the degree of pulping delignification. Thus, such properties of the two pulps are represented by a common curve.

\section{Tensile Index, Burst Index and Tear Index}

The tensile index is a representation of the fiber strength, bonding and length and is an indicator of the paper's resistance to web breaking during printing and converting (GOYAL, 20I0). The burst index measures the

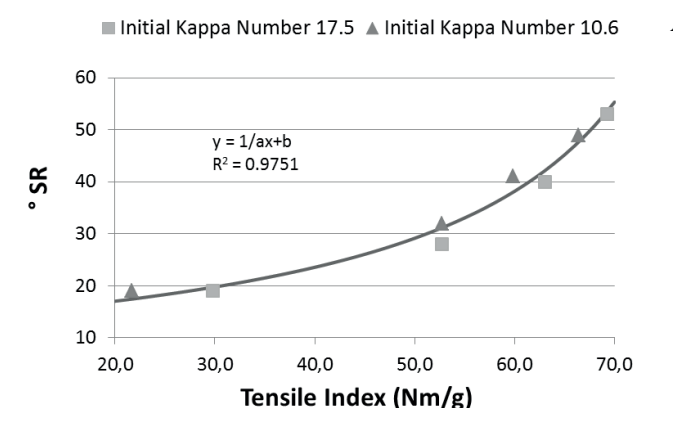

A

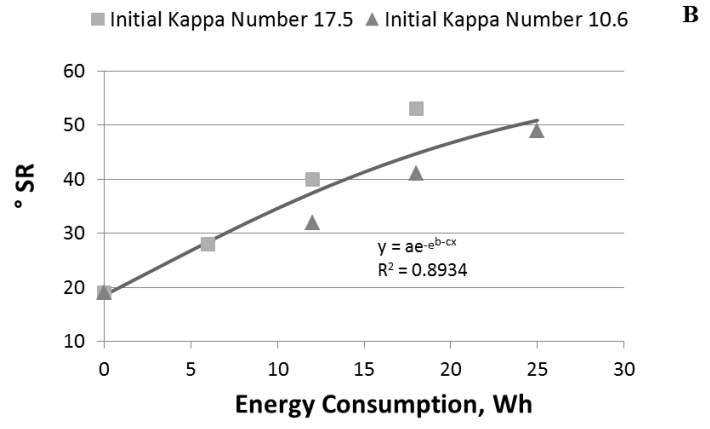

FIGURE 3 Drainage resistance (A): Schopper-Riegler versus tensile index; beatability (B): Schopper-Riegler versus energy consumption for bleached pulps cooked to two different degrees of delignification (kappa numbers of 17.5 and 10.6 ).

amount of hydrostatic pressure necessary to rupture a piece of paper and is expressed in $\mathrm{kPa} \cdot \mathrm{m}^{2} \cdot \mathrm{g}^{-1}$ (BIERMAN, 1996). The tearing resistance of paper depends on the fiber individual strength, but is also affected by fiber orientation, fiber strength, fiber length, bonding and fiber flexibility (CASEY, 1980). Figure 4 shows the relations between tensile, burst and tear index versus energy consumption for the bleached pulps with initial kappa numbers 17.5 and 10.6.

It is observed that tensile and burst index increases with energy consumption. The 17.5 kappa pulp exhibited a higher tensile and burst index than the $\mathbf{1 0 . 6}$ kappa pulp over the beating energy range examined. This difference was significant since the identity models fitted two different curves for the two pulps. The more severe cooking conditions used to obtain the 10.6 kappa pulp probably caused a decrease in pulp's xylan content, which resulted in a negative impact on tensile.

Regarding the tear index, the tendencies of the curves are different. Tear index increases in the initial phase and then decreases. This behavior is similar to eucalyptus pulps (ANDRADE, 20I0; MOREIRA, 2006). The pulps studied were statistically different. The pulp with kappa number 17.5 showed higher values of tear index in the initial phase than pulp with kappa number 10.6. Throughout the refining, this tendency was reversed. 

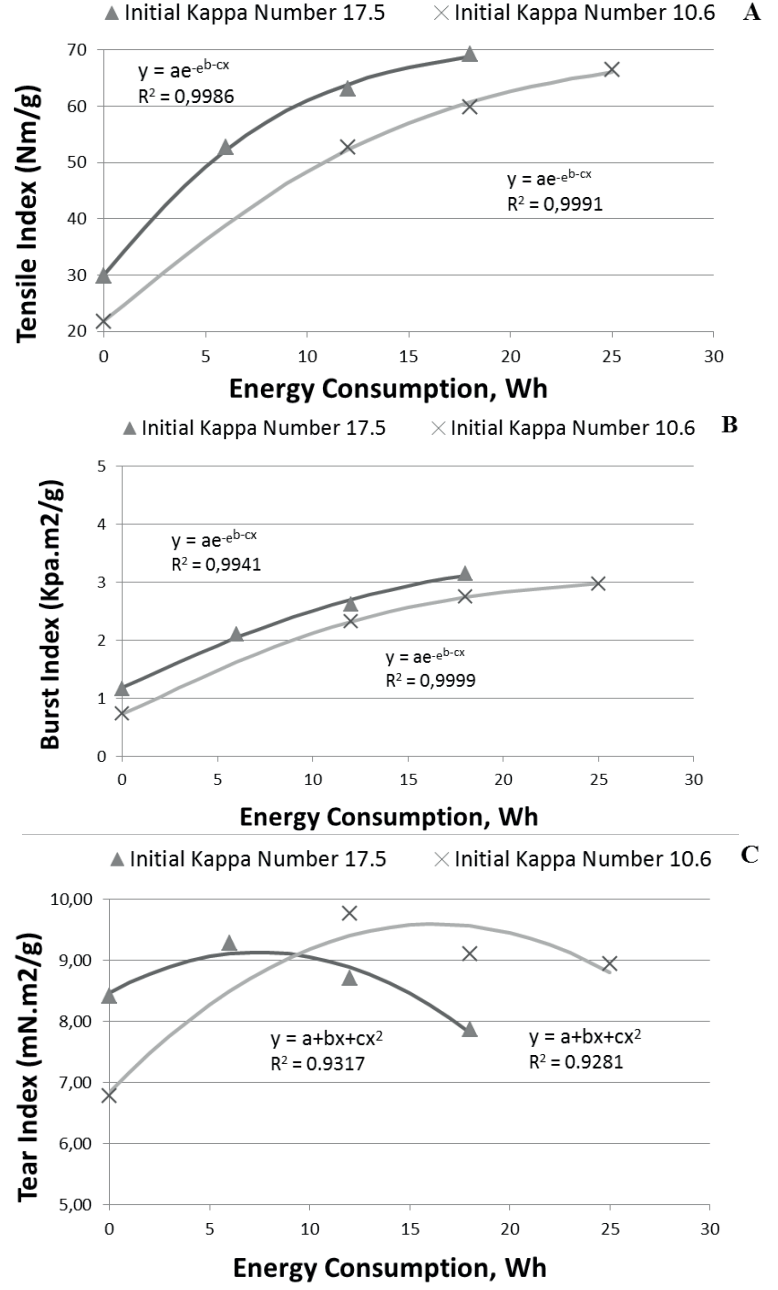

FIGURE 4 Tensile Index (A); Burst Index (B) and Tear Index (C) versus Energy Consumption for bleached pulps cooked to two different degrees of delignification (kappa 17.5 and 10.6).

\section{Specific Elastic Modulus (MOE) and Tensile Energy Absorption (TEA)}

Modulus of elasticity (MOE), also known as specific elastic modulus, is an important property because it represents the capacity of the material to absorb a tensile force without suffering substantial deformation. Higher MOE values provide greater capacity of the material to absorb a certain load without undergoing large deformations. The tensile energy absorption (TEA) represents the durability of the paper when subjected to repetitive use when subjected to tensile or impact forces. Figure 5 shows the relations of MOE and TEA with energy consumption for the two bleached pulps.

Both MOE and TEA values were higher for the pulps with kappa number 17.5 than pulps with kappa number 10.6. Probably due to drastic cooking that the pulp of lower kappa number was submitted to.

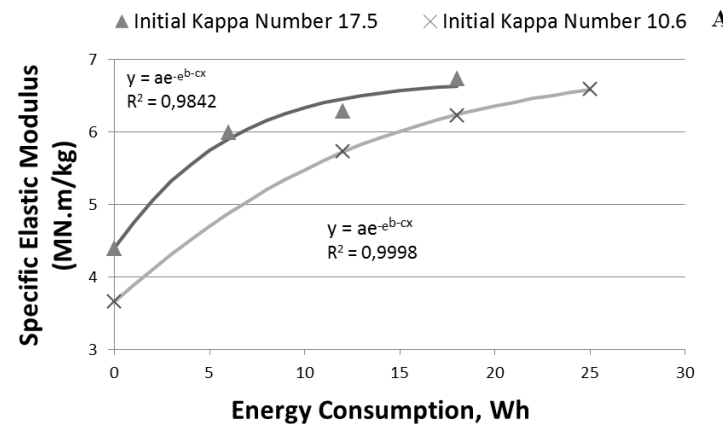

- Initial Kappa Number $17.5 \quad$ A Initial Kappa Number 10.6 B

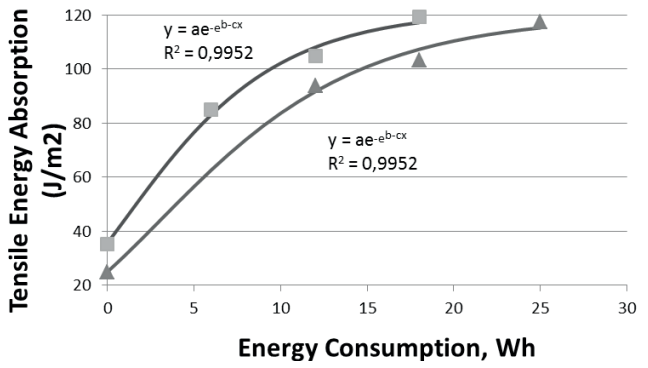

FIGURE 5 Specific elastic modulus (A) and tensile energy absorption (B) versus energy consumption for cooked bleached pulps.

\section{Resistance to air passage, Apparent Specific Weight and Apparent Specific Volume}

Air resistance has an inverse relationship with paper porosity. This property is highly and positively influenced by the amount of pulp refining. Its behavior as a function of beating energy consumption is presented in Figure 6 for the two bleached pulps. The paper sheet resistance to air passage increases with increasing energy consumption due to decreased porosity. The pulp of kappa 17.5 showed higher air resistance than that of kappa 10.6 (Figure 6). This difference was significant since the identity models fitted two different curves for the two pulps.

The apparent specific weight and volume are very important properties for printing and writing paper grade papers as they influence the porosity and opacity of paper. For a given raw material, an increase in apparent specific volume or a decrease in apparent specific weight means an increase in paper opacity and porosity. The apparent specific volume is also known as bulk. The structural characteristics of the fibers also influence the determination of this property. Less collapsible fibers contribute to increased specific volume of papers because their low conformation capacity. Figure 6 show the relations of apparent specific weight and apparent specific volume with energy consumption for the two bleached pulps. From Figure 6, it could be seen that apparent specific weight increased and apparent specific 
volume decreased with refining energy consumption. Both specific weight and volume were not significantly affected by the degree of delignification during soda pulping. Thus, such properties of the two pulps are represented by common curve.

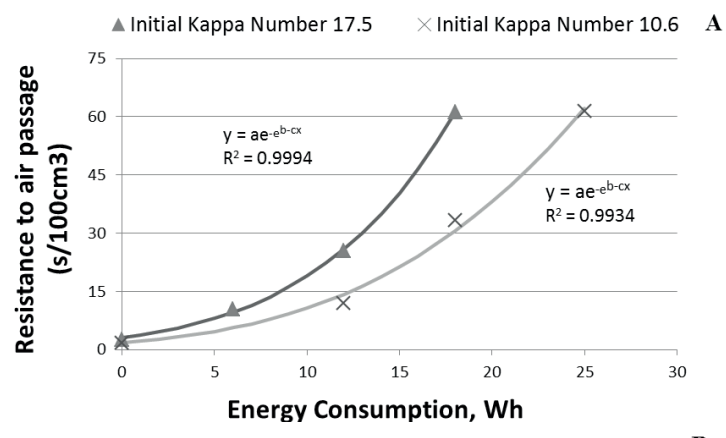

Initial Kappa Number 17.5 A Initial Kappa Number 10.6

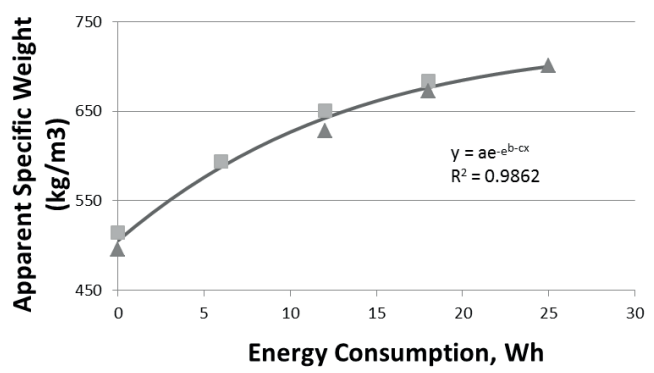

Initial Kappa Number 17.5 \& Initial Kappa Number 10.6

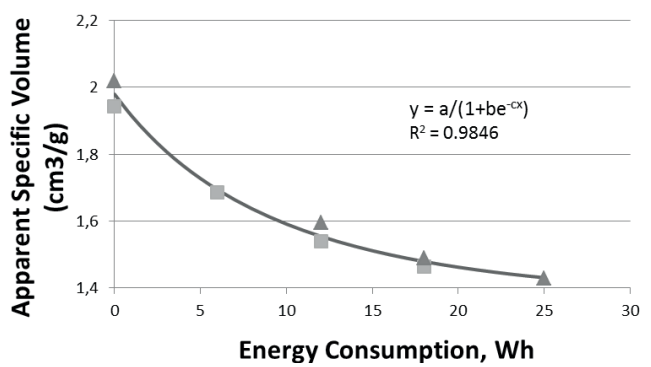

FIGURE 6 Resistance to air passage (A); apparent specific weight (B) and apparent specific volume (C) versus energy consumption for bleached pulps cooked to two different degrees of delignification (kappa I7.5 and 10.6).

\section{Opacity and Scattering Coefficient}

Opacity is defined as the ability of light to pass through a paper sheet. The extent of beating affects opacity. Opacity is important in printing and writing paper grade pulps in order to prevent the printed images or text from the opposite side from being seen from the other side of the sheet. Opacity is a function of paper thickness, amount of filler(s), pulp brightness, and beating degree. Beating makes the paper denser, but excessive beating results in low opacity (GONZÁLES et al., 20I2). The scattering coefficient is a measure of the ability of the sheet to scatter light. Figure 7 shows the relations between opacity and scattering coefficient versus energy consumption during refining for the two bleached pulps. The opacity and scattering coefficient decreases with increasing refiner energy consumption. The opacity and scattering were not influenced by the degree of pulping delignification. Thus the opacity and scattering of the two pulps is represented by common curve.

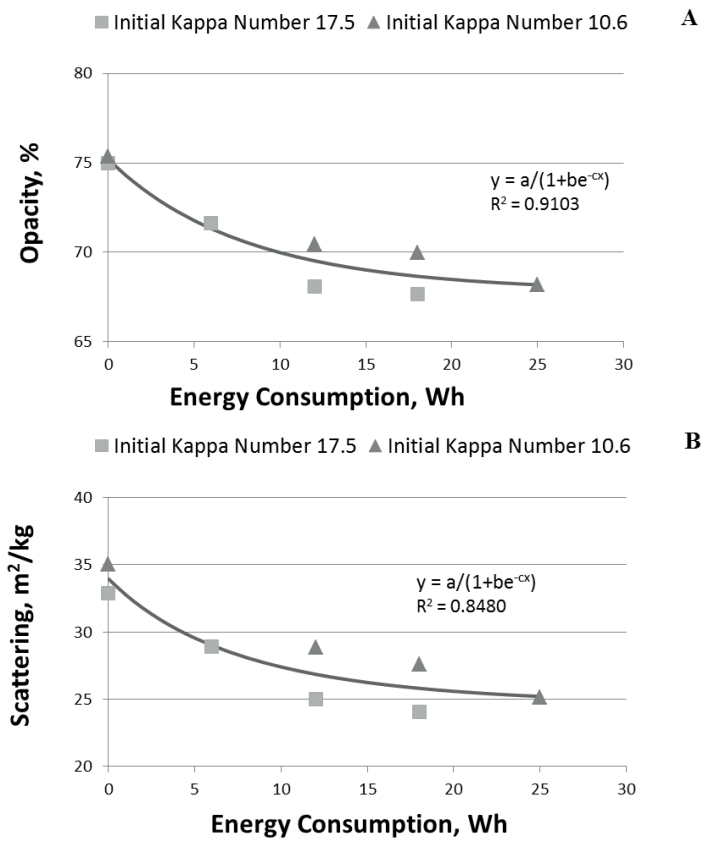

FIGURE 7 Opacity (A) and Scattering (B) versus Energy Consumption for bleached pulps cooked to two different degrees of delignification (kappa 17.5 and 10.6).

\section{Potential of bleached elephant grass soda pulp for production of printing and writing paper grade}

In order to determine the potential of the pulps produced in this study for the production of printing and writing (P\&W) paper grade, the elephant grass pulps were compared with eucalyptus pulps that are traditionally used for this application. According to Foelkel (2009), tensile and tear indexes are important for P\&W paper grades. However, other very important properties of P\&W paper grade pulps are opacity, bulk and porosity. Table 8 shows a list of relevant properties for the pulps of this study and of commercial eucalyptus P\&W paper grade kraft pulps. In general, the bleached pulps derived from elephant grass presented acceptable properties and presented similar properties with those of traditional eucalyptus kraft pulps. Considering opacity as one of the most important properties for this paper grade, opacity 
was chosen as property to be standard for comparison between elephant grass and eucalyptus pulps properties.

The strength properties of the eucalyptus kraft pulps, such as tensile and burst index, were generally higher than those of the elephant grass soda pulps. But tear index showed similar values for elephant grass and eucalyptus pulps. Both the eucalyptus and elephant grass raw materials had similar fiber morphology; the fiber viscosities of the eucalyptus kraft pulps were similar to the elephant grass pulp. However, the values from eucalyptus kraft pulps were slightly higher than those of the elephant grass pulp. The values of bulk $(\sim 1.5$ $\left.\mathrm{cm}^{3} \cdot \mathrm{g}^{-1}\right)$ and opacity ( $\left.70 \%\right)$, which are very important properties for printing and writing paper grades, were similar for eucalyptus kraft and elephant grass pulps. Yet, when comparing the elephant grass pulps with eucalyptus pulps (Eucalyptus grandis), the variations between the physico-mechanical properties values were small. Values of bulk, tensile index, burst index and opacity were $1.5 \mathrm{~cm}^{3} \cdot \mathrm{g}^{-1}, 56.5 \mathrm{~N} \cdot \mathrm{m} \cdot \mathrm{g}^{-1}, 3.6 \mathrm{kPa} \cdot \mathrm{m}^{2} \cdot \mathrm{g}^{-1}$, and $71.9 \%$, respectively for the Eucalyptus grandis pulps.

\section{CONCLUSIONS}

The morphological analyses of the elephant grass indicated a short fiber material, similar to hardwoods.

The bleached soda pulps cooked to I7.5 and I0.6 kappa numbers showed similar refinability and resistance to drainage, but the tensile and burst index were highest for the I7.5 kappa pulp.

Both bleached pulps (I7.5 and 10.6 kappa) obtained from elephant grass were suitable for production of printing and writing paper grades; however, the highest kappa pulp was more economically attractive given its highest pulping yield, despite the significantly increased bleaching chemical demand.

In general, the bleached pulps derived from elephant grass presented acceptable properties and presented similar properties when compared to those of traditional eucalyptus kraft pulps.

\section{REFERENCES}

ALMEIDA, D. P.; GOMIDE, J. Polpação Soda com Aditivos e Cinética da Deslignificação Kraft. 2014. 44p. PhD thesis. Universidade Federal de Viçosa, Viçosa, MG.

ANDERSON, J.R. Hydrogen peroxide use in chemical pulping bleaching. TAPPI Bleach Plant Operations Short Course Notes, Tappi Press, p. 123. 1992.

ANDRADE, M. F. Comparative study on the bleachability of kraft pulp from Pinus radiata and a mixture of Eucalyptus globulus and Eucalyptus nitens. 2010. $105 f$. Master thesis. University Federal of Viçosa, Viçosa, MG.

ANDRADE, M. F; COLODETTE, J. L. Dissolving pulp production from sugar cane basse. Ind. Crop. Prod. v. 52 p. 58-64. 2014.

BARBOSA, L. C. A., MALTHA, C. R. A., and CRUZM. P. Chemical composition of lipophilic and polar extractives of Eucalyptus grandis. Science \& Eng. J. v. 15, n.2, p. I3-20. 2005.

BASSA, A.; BASSA, A.G.M.C.; SACON, V.M.; VALLE, C. F. Seleção e caracterização de clones de eucalipto considerando parâmetros silviculturais, tecnológicos e de produto final. Disponível em: http://www. eucalyptus.com.br/icep02/alexandre_bassa.pdf. Acesso em: $01 / 06 / 2016$.

BATALHA, L. A. R, COLODETTE, J. L., GOMIDE J. L., BARBOSA, L. C. A., MALTHA, C. R. A., GOMES, F. J. B. Dissolving pulp production from bamboo. BioRes. V. 7, n. I, p. 640-65I. 2012.

BIERMAN, C.J.. Handbook of pulping and papermaking. 2ed. Academic Press, USA. 754p. 1996.

CARVALHO, D. M. Evaluation of the Ethanol /Soda Cooking for Sugar Cane Bagasse and Straw. 2012. I50f. Master thesis - University Federal of Viçosa, Viçosa, MG.

CASEY, J. P. Pulp and Pap. Chem. and Tech., 3rd Edition Vol.2, John Wiley \& Sons Inc., New York. 1980.

DEL RÍO, J. C., PRINSEN, P., RENCORET, J., NIETO, L., JIMÉNEZ-BARBERO, J., RALPH, J., MARTÍNEZ, Á. T., AND GUTIERREZ. Structural characterization of the lignin in the cortex and pith of elephant grass (Pennisetum purpureum) stems. J. of Agric. and Food Chem. V. 60, n. 14, p. 3619-3634. 2012.

TABLE 8 Parameters estimates of the omnidirectional and cross semivariograms Vol = volume, Exp = Exponential.

\begin{tabular}{ccccccccc}
\hline Sample & $\begin{array}{c}\text { Opacity } \\
(\%)\end{array}$ & $\begin{array}{c}\text { Mill } \\
\text { Revolutions }\end{array}$ & ${ }^{\circ} \mathrm{SR}$ & $\begin{array}{c}\text { Bulk } \\
\left(\mathrm{cm}^{3} \cdot \mathrm{g}^{-1}\right)\end{array}$ & $\begin{array}{c}\text { Tensile Index } \\
\mathrm{N} \cdot \mathrm{m} \cdot \mathrm{g}^{-1}\end{array}$ & $\begin{array}{c}\text { Burst Index } \\
\mathrm{kPa} \cdot \mathrm{m}^{2} \cdot \mathrm{g}^{-1}\end{array}$ & $\begin{array}{c}\text { Tear Index } \\
\mathrm{mN} \cdot \mathrm{m}^{2} \cdot \mathrm{g}\end{array}$ & $\begin{array}{c}\text { Air Resistance } \\
\mathrm{s} \cdot\left(\mathrm{I00} \mathrm{cm}^{3}\right)^{-1}\end{array}$ \\
\hline EG KN: I7.5 & 71.6 & 500 & 28 & 1.7 & 52.7 & 2.1 & 9.3 & 10.5 \\
EG KN:10.6 & 70.4 & 1000 & 32 & 1.6 & 52.7 & 2.3 & 9.8 & 11.8 \\
Eucalyptus Hybrid * & 70.8 & 1793 & 34 & 1.4 & 78.0 & 5.4 & 10.5 & 4.6 \\
Eucalyptus Hybrid * & 74.1 & 1184 & 34 & 1.6 & 66.2 & 4.6 & 8.6 & 3.8 \\
Eucalyptus Hybrid ** & 70.7 & 3000 & 40 & 1.2 & 77.0 & 4.8 & 9.0 & 31.3 \\
Eucalyptus Grandis *** & 72.9 & 1000 & 33 & 1.5 & 56.5 & 3.6 & 9.8 & 8.9 \\
\hline
\end{tabular}

* Bassa et. al. (2005). ** Andrade (2010). *** Pedrazzi (2009). 
FOELKEL, C.E.B. Propriedades papeleiras das árvores, madeiras e fibras celulósicas dos eucaliptos. In: Eucalyptus Online Book \& Newsletter, 2009. I I Ip. . Online. Available at: http://www.eucalyptus.com.br/eucaliptos/PTI4_ PropPapeleiras.pdf. Accessed in: 0I jun. 2016.

FOELKEL, C.E.B.; BARRICHELO, L.E.G. Relações entre características da madeira e propriedades da celulose e papel. O Papel. V. 36, n. 9, p, 49-53. 1975.

FORSKAHL, I., POPOFF, T., and THEANDER, O. Reactions of DXylose and D-Glucose in Alkaline Aqueous Solutions. Carbohydrate Res., v. 48, p. 3-2I. 1976.

GIERER, J. The Reactions of Lignin during Pulping. Svensk Papperstidn. v. 73, p. 57I-597. 1970.

GOLDSCHMIDT, O. Ultraviolet Spectra Lignin: occurrence, formation, structure and reactions. In: SARKANEN, K. V.; LUDWIG, C. H. (Eds.). New York: Wiley Interscience. p.24I-266. I97I.

GOMES, F. J. B.; COLODETTE, J. L.; BURNET, A.; BATALHA, L. A. R.; BARBOSA, B. M. Potential of elephant grass for pulping production. BioRes. v. 8 n. 3, p. 4359-4379. 2013.

GOMIDE, J. L.; DEMUNER, B. J. Determinação do teor de lignina na madeira: método Klason modificado. O Papel. V. 47, n. 8, p. 36-38. 1986.

GONZÁLES, I.; BOUFI, S.; PÈLACH, M. A.; ALCAIÀ, M.; VILASECA, F. and MUTJÉ, P. Nanocellulse paper additive. BioRes. V. 7, n. 4, p. 5I67-5I80. 2012.

LACHENAL, D.; CHIRAT, C. High Temperature Chlorine Dioxide Bleaching of Hardwood Kraft Pulp. Tappi J. v. 83, n. 8, p. 96.2010.

LIN, S.Y.; DENCE, C.W. Methods in lignin chemistry. Springer-Verlag. .Berlin. 1992. 578p.

MADAKADZE, I. C., MASAMVU, T. M., RADIOTIS, T., LI, J., and SMITH, D. L. Evaluation of pulp and paper making characteristics of elephant grass (Pennisetum purpureum Schum) and switchgrass (Panicum virgatum L.). African J. of Environmental Science and Technol. v. 4, n. 7, p. 465-470. 2010.

MAGATON, A. S., PILO-VELOSO, D., and COLODETTE, J. L. Characterization of acetil-(4-O-methylglucurono) xylans from Eucalyptus urograndis. Química Nova. V. 3I, n. 5, p. 1085-1088. 2008

MOREIRA, E. Efeito da lixiviação ácida de cavacos de eucalipto no processo Kraft. 122 p. Master thesis. University Federal of Viçosa, Viçosa, MG. 2006.

PANDEY, A., SOCCOL, C.R., NIGAM, P. and SOCCOL, V.T. Biotechnological potential of agro-industrial residues. Part I. Sugarcane bagasse. Biores. Technol. 74, p. 6980. 2000.
PRINSEN, P., GUTIÉRREZ, A., and DEL RÍO, J. C. Lipophilic extractives from the cortex and pith of elephant grass (Pennisetum purpureum Schumach.) stems. J. of Agric. and Food Chem. V. 60, n. 25, p. 6408-64I7. 2012.

REGAZZI, A. Teste para identificar a identidade de modelos de regressão e igualdade de alguns parâmetros num modelo polinomial ortogonal. Revista Ceres. Viçosa, v. 40, n. 228, p. 176-195. 1993.

REGAZZI, A.; SILVA, C. H. O. Teste para verificar a igualdade de parâmetros e a identidade de modelos de regressão não-linear. I. Dados no delineamento inteiramento casualizado. Revista Matemática Estatística, São Paulo, v. 22, n. 3, p. 33-45. 2004.

SAIN M.; PANTHAPULAKKAL S. Bioprocess preparation of wheat straw fibers and their characterization. Ind. Crops. Prod. v. 23, n. I, p. I-8. 2006.

SCOTT, R. W. Calorimetric determination of hexunoric acid in plant materials. Analytical Chem. V. 5I, n. 7, p. 936941. 1979.

SOLAR R, KACIKF, MELCERI. Simple method for determination of O-acetyl groups in wood and related materials. Nord. Pulp and Pap. Res. J. n.4, p. I39-I4I. 1987.

SOMERVILLE, C.; YOUNGS, H.; TAYLOR, C.; DAVIS, S. C.; LONG, S. P. Feedstocks for lignocellulosic biofuels. Science. V. 329, n. 5993, p. 790-792. 2010.

PEDRAZZI, C. Influência das xilanas na produção e nas propriedades de polpas de Eucalyptus grandis e Eucalyptus urograndis. 194f. Doctor Thesis - University Federal of Viçosa, Viçosa, MG. 2009.

VENTORIM, G.; COLODETTE, J. L.; EIRAS, K. M. M. O destino de espécies de cloro durante o branqueamento com dióxido de cloro a altas temperaturas. O Papel. v. 70, n. 8 , p. $39-50.2009$.

VERVERIS C, GEORGHIOU K, CHRISTODOULAKIS N, SANTAS P, SANTAS R. Fiber dimensions, lignin and cellulose content of various plant materials and their suitability for paper production. Ind. Crops Prod. V.19, n. 3, p.245-254. 2004.

XIE, X. M., ZHANG, X. Q., DONG, Z. X., and GUO, H. R. Dynamic changes of lignin contents of MT-I elephant grass and its closely related cultivars. Biomass \& Bioenergy. V. 35 , n. 5, p.1732-1738. 201 I.

WALLIS A.; WEARNE R.; WRIGHT P. Chemical analysis of polysaccharides in plantation eucalypt woods and pulps. Tappi J. v. 49, n.4, p. 258-262. 1996. 
